\title{
Bovine milk contains microRNA and messenger RNA that are stable under degradative conditions
}

\author{
H. Izumi, ${ }^{* 1}$ N. Kosaka, $†$ T. Shimizu, ${ }^{*}$ K. Sekine, ${ }^{*}$ T. Ochiya, $†$ and M. Takase ${ }^{\star}$ \\ ${ }^{*}$ Nutritional Science Institute, Morinaga Milk Industry Co., Ltd., Zama, Kanagawa 252-8583, Japan \\ †Division of Molecular and Cellular Medicine, National Cancer Center Research Institute, Chuo-ku, Tokyo 104-0045, Japan
}

\begin{abstract}
We previously reported that microRNA (miRNA) is present in human breast milk. Recently, other groups have reported that bovine milk also contains miRNA; however, these reports are few. We therefore investigated bovine milk miRNA using microarray and quantitative PCR analyses to identify the differences between colostrum and mature milk. The RNA concentration in a colostrum whey fraction was higher than that in a mature milk whey fraction. In total, 102 miRNA were detected in bovine milk by microarray analysis (100 in colostrum and 53 in mature milk; 51 were common to both). Among these miRNA, we selected several immune- and development-related miRNA, including miR-15b, miR-27b, miR-34a, miR-106b, miR-130a, miR-155, and miR-223. These miRNA were detected in bovine milk by quantitative PCR, and each of these miRNA was significantly more highly expressed in colostrum than in mature milk. We also confirmed the presence of some mRNA in bovine milk. Nevertheless, synthesized miRNA spiked in the raw milk whey were degraded, and naturally existing miRNA and mRNA in raw milk were resistant to acidic conditions and RNase treatment. The RNA molecules in milk were stable. We also detected miRNA and mRNA in infant formulas purchased from Japanese markets. It is still unknown whether milk-derived RNA molecules play biological roles in infants; however, if milk-derived RNA do show functions in infants, our data will help guide future studies.
\end{abstract}

Key words: microRNA, mRNA, milk, bovine

\section{INTRODUCTION}

Milk is the only nutritional source for newborn mammals; however, large differences exist in the nutritional components of different mammalian milks, which are adapted for offspring development (Davis et

Received February 28, 2012.

Accepted May 13, 2012.

${ }^{1}$ Corresponding author: h-izumi@morinagamilk.co.jp al., 1994; Jensen, 1995). Moreover, the growth factors in milk have been reported to exert biological effects on the neonatal small intestine, and neonatal intestinal epithelial cells express receptors for growth factors and hormones (Burrin and Stoll, 2002). Additionally, some milk components and digested milk proteins have been reported to stimulate the secretion of intrinsic growth factors or hormones in neonates (Burrin and Stoll, 2002; Izumi et al., 2009). Milk also contains immunerelated components, including cytokines, IgA, lactoferrin, lysozyme, and sialic acids, and it is considered to provide protection against early infections in neonates (Goldman, 2007; Walker, 2010).

In addition to these components, we previously reported that human breast milk contains immunerelated microRNA (miRNA; Kosaka et al., 2010b). In that study, organ-specific miRNA (blood cell-, muscle-, pancreas-, and liver-specific) were not detected, but immune-related miRNA (e.g., miR-155, miR-181, and miR-223) were detected. MicroRNA are endogenous, noncoding, small RNA molecules, 19 to 24 nucleotides long, that play important regulatory roles in gene expression by base-pairing with complementary sites in target mRNA molecules, thereby blocking translation or triggering the degradation of the target mRNA. The biological functions of most miRNA are unknown, but it is estimated that $>30 \%$ of protein-coding genes are regulated by miRNA (Lewis et al., 2005).

Following our previous study (Kosaka et al., 2010b), Weber et al. (2010) published a study of miRNA in 12 human body fluids, including breast milk. According to these 2 studies (Kosaka et al., 2010b; Weber et al., 2010), milk miRNA profiles differ considerably between individuals. This suggests that milk miRNA profiles are influenced by aspects of the mother's background (e.g., race and lifestyle).

Bovine milk is widely used as a dairy product, including in infant formula, and it is an important material in the food industry. Two groups have reported that bovine milk also contains miRNA (Chen et al., 2010; Hata et al., 2010). However, few reports have been published on milk miRNA, and their profiles could differ according to the cows' environment, as in humans, 
Table 1. Information on collected colostrum and mature milk samples (parturient history of cow, collection timing, collected volume, and volume to used to purify RNA)

\begin{tabular}{|c|c|c|c|c|}
\hline Type/sample no. & $\begin{array}{c}\text { Parturient } \\
\text { history of cow } \\
\text { (no. of times) }\end{array}$ & $\begin{array}{c}\text { Sample } \\
\text { collection time } \\
\text { (d or mo after } \\
\text { parturition) }\end{array}$ & $\begin{array}{l}\text { Collected } \\
\text { milk volume } \\
(\mathrm{mL})\end{array}$ & $\begin{array}{l}\text { Volume used } \\
\text { to purify } \\
\text { RNA (mL) }\end{array}$ \\
\hline \multicolumn{5}{|l|}{ Colostrum } \\
\hline 1 & 6 & $1 \mathrm{~d}$ & 20 & 4 \\
\hline 2 & 1 & $1 \mathrm{~d}$ & 20 & 4.5 \\
\hline 3 & 1 & $1 \mathrm{~d}$ & 30 & 2.5 \\
\hline 4 & 1 & $2 \mathrm{~d}$ & 20 & 5.5 \\
\hline 5 & 1 & $3 \mathrm{~d}$ & 30 & 2.5 \\
\hline \multicolumn{5}{|l|}{ Mature milk } \\
\hline 6 & 4 & $8 \mathrm{~d}$ & 12 & 4 \\
\hline 7 & 2 & $3.5 \mathrm{mo}$ & 12 & 6.5 \\
\hline 8 & 3 & $6 \mathrm{mo}$ & 12 & 3.5 \\
\hline 9 & 3 & $7 \mathrm{mo}$ & 12 & 4 \\
\hline 10 & 8 & $8 \mathrm{mo}$ & 10 & 4 \\
\hline
\end{tabular}

and information is limited on the time-dependent expression pattern after delivery. Thus, in this study, we investigated bovine milk miRNA using microarray and quantitative PCR (qPCR) analyses to identify the differences between colostrum and mature milk.

We also confirmed that mRNA are present in bovine milk. These miRNA and mRNA were resistant to acidic conditions and RNase treatment; thus, we concluded that the RNA in milk are highly stabilized and could be resistant to industrial processing. We therefore investigated the miRNA and mRNA in infant formulas that are commercially available in Japan, and we found both types of RNA. Recently, it has been reported that orally acquired exogenous plant miRNA are present in human and mouse sera and tissues, and that these exogenous plant miRNA can regulate the expression of target genes in mammals (Zhang et al., 2012). If RNA derived from milk can be absorbed in the human intestine and exhibit protein-like functions, future studies are needed to evaluate the roles of milk- and infant formula-derived RNA.

\section{MATERIALS AND METHODS}

\section{Milk Sample Preparation}

Bovine colostrum and mature milk samples were collected from 10 healthy Holstein cows within $3 \mathrm{~d}$ postpartum for colostrum ( 5 cows), and after $8 \mathrm{~d}$ postpartum for mature milk ( 5 cows; Table 1 ). All procedures in this study were performed in accordance with the Guide for the Care and Use of Laboratory Animals of Morinaga Milk Industry Co. Ltd. (Kanagawa, Japan). The milk samples were stored at $-20^{\circ} \mathrm{C}$ immediately after collection and were later transferred to our laboratory and stored at $-80^{\circ} \mathrm{C}$ until use. The samples were centrifuged twice $\left(1,200 \times g, 4^{\circ} \mathrm{C}, 10 \mathrm{~min}\right)$ to remove fat, cells, and large debris. The defatted supernatant was then centrifuged $\left(21,500 \times g, 4^{\circ} \mathrm{C}, 30 \mathrm{~min}, 1 \mathrm{~h}\right)$ to remove residual fat and casein. The clear supernatant (whey) was then passed through 0.65-, 0.45-, and 0.22$\mu \mathrm{m}$ filters to remove residual cell debris and analyzed.

\section{Extraction of Total RNA}

Total RNA was extracted from the milk samples was using an miRNeasy Mini Kit (Qiagen, Hilden, Germany). The whey samples (see above) were diluted with 5 volumes of QIAzol Lysis Reagent (Qiagen), mixed thoroughly by vortexing, and incubated for 5 min at $25^{\circ} \mathrm{C}$ (denatured samples). In the field of body fluid miRNA research, there is no established endogenous small RNA control. Therefore, to normalize the miRNA expression data obtained by qPCR, synthetic Caenorhabditis elegans cel-miR-39 (miScript miRNA Mimic, Qiagen; $10 \mathrm{fmol}$ in a $2-\mu \mathrm{L}$ volume) was added to $1.2 \mathrm{~mL}$ of denatured sample (Mitchell et al., 2008; Kosaka et al., 2010b). Next, chloroform (equal volume to the volume of whey) was added to the homogenate, which was mixed thoroughly by vortexing, incubated for $3 \mathrm{~min}$ at room temperature, and centrifuged $(12,000$ $\left.\times g, 4^{\circ} \mathrm{C}, 15 \mathrm{~min}\right)$. The resulting aqueous phase was mixed thoroughly with 1.5 volumes of $100 \%$ molecular biology-grade ethanol and passed through an miRNeasy column. The RNA was eluted in nuclease-free water. The quantity and integrity of the RNA were assessed on an Agilent 2100 Bioanalyzer using an RNA 6000 Pico Kit (both from Agilent Technologies, Santa Clara, CA).

\section{Microarray Analysis}

To detect the expression of miRNA in bovine milk, $20 \mathrm{ng}$ of total RNA was labeled with cyanine-3 and 
$20 \mathrm{ng}$ total RNA

Calf intestine alkaline phosphatase treatment $37^{\circ} \mathrm{C}, 30 \mathrm{~min}$

\section{Dephosphorylated RNA}

Labeled with cyanine 3-cytidine biphosphate using T4 RNA ligase, $16^{\circ} \mathrm{C}, 2 \mathrm{~h}$

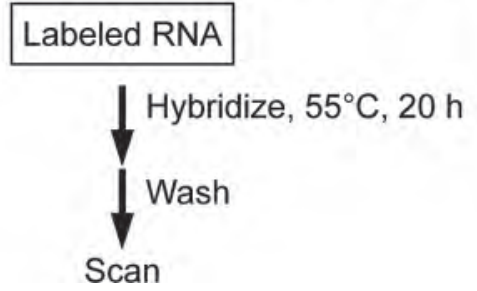

Figure 1. Flowchart of microRNA microarray analysis.

hybridized to a Bovine miRNA Microarray Rel. 13.0 microarray using an miRNA Complete Labeling Reagent and Hyb Kit (Agilent Technologies; Figure 1). The Bovine miRNA Microarray Rel. 13.0 microarray screens for the expression of 333 bovine miRNA from Sanger miRBase Rel.13.0 (http://www.mirbase.org/). Signals were detected with an Agilent DNA Microarray Scanner, and the scanned images were analyzed using Feature Extraction Software (ver. 9.5.3.1). The microarray data were analyzed using GeneSpring GX ver. 11.5.1 (Agilent Technologies).

\section{Quantification of miRNA by $q P C R$}

Complementary DNA was generated using an miScript Reverse Transcription Kit (Qiagen). In brief, $50 \mathrm{ng}$ of RNA was polyadenylated using poly(A) polymerase, and cDNA was generated with reverse transcriptase using tagged oligo-dT primers (Figure 2A). The cDNA was then diluted in 9 volumes of nuclease-free water and subjected to qPCR on a 7500 Fast Real-Time PCR System (Applied Biosystems, Foster City, CA) using an miScript SYBR Green PCR Kit and miScript Primer Assay (both from Qiagen). The following real-time PCR protocol was used: initial activation of HotStarTaq DNA Polymerase $\left(95^{\circ} \mathrm{C}, 15 \mathrm{~min}\right)$; 40 to 50 cycles of denaturation $\left(94^{\circ} \mathrm{C}, 15 \mathrm{~s}\right)$, annealing $\left(55^{\circ} \mathrm{C}, 30 \mathrm{~s}\right)$, and extension $\left(70^{\circ} \mathrm{C}, 34 \mathrm{~s}\right)$; and melting curve analysis. The miScript Primer Assays for the target miRNA we used are listed in Table 2. The data were analyzed using 7500 Software ver. 2.0.4. (Applied Biosystems) with the fixed cycle threshold $(\mathbf{C t})$ setting $(\Delta \mathrm{Rn}=0.02$, where $\Delta \mathrm{Rn}$ is the fluorescence of the reporter dye minus the
(A)

\section{$50 \mathrm{ng}$ total RNA}

Polyadenylation by poly $(A)$ polymerase Converted into CDNA by reverse transcriptase with oligo-dT priming $37^{\circ} \mathrm{C}, 60 \mathrm{~min}$

Reverse transcriptase inactivation $95^{\circ} \mathrm{C}, 5 \mathrm{~min}$

cDNA

\begin{tabular}{l}
$\downarrow$ Dilution in 9 volumes of nuclease-free water \\
qPCR \\
\hline
\end{tabular}

(B)

\section{$50 \mathrm{ng}$ total RNA}

Converted into cDNA by reverse transcriptase with a primer cocktail (oligo-dT and random primers) Step1: $25^{\circ} \mathrm{C}, 5 \mathrm{~min}$, Step 2: $42^{\circ} \mathrm{C}, 30 \mathrm{~min}$

Reverse transcriptase inactivation $85^{\circ} \mathrm{C}, 5 \mathrm{~min}$

cDNA

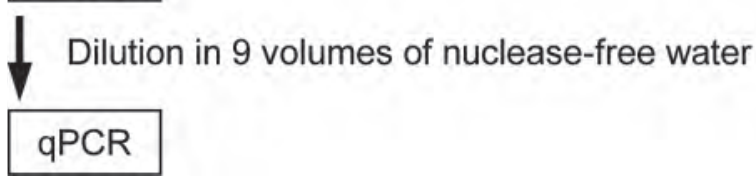

Figure 2. Flowchart of cDNA synthesis for quantitative (q)PCR analysis: (A) cDNA synthesis for quantification of microRNA by qPCR; (B) cDNA synthesis for quantification of mRNA by qPCR.

baseline) to assign baseline values and the threshold for $\mathrm{Ct}$ determination. In the case of normalization, the data were normalized to the spiked-in control celmiR-39 using the $\Delta \Delta \mathrm{Ct}$ method.

\section{Quantification of mRNA by $q P C R$}

Complementary DNA for the quantification of mRNA was generated using a High Capacity RNA-to-cDNA Kit (Applied Biosystems). In brief, $50 \mathrm{ng}$ of RNA was used to generate cDNA with reverse transcriptase and a primer cocktail (oligo-dT and random primers; Figure 2B). The cDNA was diluted in 9 volumes of nucleasefree water and then subjected to qPCR on a 7500 Fast Real-Time PCR System using TaqMan Fast Advanced Master Mix and TaqMan Probes (both from Applied 
Table 2. Primers (miScript, Qiagen, Hilden, Germany) used for microRNA (miRNA) assay

\begin{tabular}{lll}
\hline Number & miRNA & Product No. \\
\hline 1 & let-7a & MS00005460 \\
2 & let-7b & MS00000007 \\
3 & let-7c & MS00005467 \\
4 & let-7f & MS00005481 \\
5 & miR-15b & MS00013097 \\
6 & miR-20a & MS00000098 \\
7 & miR-24 & MS00005537 \\
8 & miR-26a & MS00000133 \\
9 & miR-27b & MS00000154 \\
10 & miR-29b & MS00005544 \\
11 & miR-29c & MS00000175 \\
12 & miR-34a & MS00000224 \\
13 & miR-92a & MS00006594 \\
14 & miR-103 & MS0000000301 \\
15 & miR-106b & MS00005600 \\
16 & miR-125b & MS00000343 \\
17 & miR-130a & MS00007252 \\
18 & miR-133a & MS00007259 \\
19 & miR-133b & MS00000413 \\
20 & miR-141 & MS00003556 \\
21 & miR-148a & MS00003605 \\
22 & miR-155 & MS00013139 \\
23 & miR-181d & MS00003752 \\
24 & miR-200c & MS00003871 \\
25 & miR-223 & MS00013433 \\
26 & miR-320 & MS00004340 \\
27 & miR-494 & \\
\hline & & \\
\hline & &
\end{tabular}

Biosystems), which contain target-specific forward and reverse primers as well as target-specific probes labeled with a fluorescent dye. The following real-time PCR protocol was used: uracil- $N$-glycosylase incubation $\left(50^{\circ} \mathrm{C}, 2 \mathrm{~min}\right)$; polymerase activation $\left(95^{\circ} \mathrm{C}, 20 \mathrm{~s}\right) ; 40$ to 50 cycles of denaturation $\left(95^{\circ} \mathrm{C}, 3 \mathrm{~s}\right)$, and annealing and extension $\left(60^{\circ} \mathrm{C}, 30 \mathrm{~s}\right)$. The TaqMan Probes used for the target mRNAs are listed in Table 3. The data were analyzed using 7500 Software ver. 2.0.4. (Applied
Biosystems $)$ with the fixed $\mathrm{Ct}$ setting $(\Delta \mathrm{Rn}=0.2)$ to assign baseline values and the threshold for $\mathrm{Ct}$ determination.

\section{RNase and Detergent Treatment and Acidification}

To assess whether the milk RNA were resistant to physiological temperature, RNase, acidic conditions, and detergent, raw milk whey fractions were treated with RNase $(10 \mathrm{U} / \mathrm{mL}$ RNase A and $400 \mathrm{U} / \mathrm{mL}$ RNase $\mathrm{T}$; Ambion, Austin, TX) at $37^{\circ} \mathrm{C}$ for $1 \mathrm{~h}$, incubated at $\mathrm{pH} 2$ (by adding $\mathrm{HCl}$ ) at $37^{\circ} \mathrm{C}$ for $1 \mathrm{~h}$, or treated with 1\% Triton X-100 (Nacalai Tesque, Kyoto, Japan) at $37^{\circ} \mathrm{C}$ for $1 \mathrm{~h}$. As a control, raw miRNA, synthetic cel-miR-54 (Qiagen) (10 fmol in a $2-\mu \mathrm{L}$ volume) was added to denatured or raw whey $(200 \mu \mathrm{L}$ of whey). One-quarter of each total RNA sample was used for cDNA synthesis as described above. For quantification of the miRNA and mRNA, 1/50th of the synthesized cDNA was used.

\section{Preparation of Milk Formula}

We prepared a standard infant formula $(11.7 \mathrm{~g}$ of protein, $56.3 \mathrm{~g}$ of carbohydrate, $27.0 \mathrm{~g}$ of fat, $2.3 \mathrm{~g}$ of mineral/100 $\mathrm{g}$ of powder), a follow-on formula (which is used for children from 9 mo to about 2 or $3 \mathrm{yr}, 14.0$ $\mathrm{g}$ of protein, $61.0 \mathrm{~g}$ of carbohydrate, $18.0 \mathrm{~g}$ of fat, $4.0 \mathrm{~g}$ of mineral/100 g of powder), and a casein whey-based extensively hydrolyzed formula (which is used for milkallergic infants, $12.6 \mathrm{~g}$ of protein, $62.2 \mathrm{~g}$ of carbohydrate, $20.0 \mathrm{~g}$ of fat, $2.5 \mathrm{~g}$ of mineral/100 $\mathrm{g}$ of powder), all of which are available in Japanese markets. To prepare whey fractions from these formulas, we dissolved each powdered formula in ultrapure (Milli Q, Millipore, Billerica, MA) water at a standard concentration (13-14\%)

Table 3. TaqMan (Applied Biosystems, Foster City, CA) probes used for the mRNA assay

\begin{tabular}{|c|c|c|}
\hline No. & mRNA & Product No. \\
\hline 1 & $\alpha_{\mathrm{S} 1}$-Casein & Bt03217569_m1 \\
\hline 2 & $\alpha_{S 2}$-Casein & Bt03214949_m1 \\
\hline 3 & $\beta$-Casein & Bt03217427_m1 \\
\hline 4 & $\kappa$-Casein & Bt03213724_m1 \\
\hline 5 & $\alpha$-Lactalbumin & Bt03213962_m1 \\
\hline 6 & $\beta$-Lactoglobulin & Bt03230916_m1 \\
\hline 7 & Lactoferrin & Bt03217384_m1 \\
\hline 8 & Lactoperoxidase & Bt03211919_m1 \\
\hline 9 & Milk fat globule-EGF 8 & Bt03216859_m1 \\
\hline 10 & Polymeric immunoglobulin receptor & Bt03212948_m1 \\
\hline 11 & Xanthine oxidase & Bt03212108_m1 \\
\hline 12 & CD36 & Bt03212338_m1 \\
\hline 13 & CD63 & Bt03217862_m1 \\
\hline 14 & Major histocompatibility complex class II & Bt03286221_g1 \\
\hline 15 & Fatty acid synthase & Bt03210485_m1 \\
\hline 16 & Enolase $1 \alpha$ & Bt03230941_m1 \\
\hline
\end{tabular}


according to the manufacturer's protocol, and then centrifuged at $1,200 \times \mathrm{g}$ for $10 \mathrm{~min}$ at $4^{\circ} \mathrm{C}$ and twice at $21,500 \times g$ for $30 \mathrm{~min}$ and $1 \mathrm{~h}$ at $4^{\circ} \mathrm{C}$ and filtered the resulting whey as described above. Total RNA was extracted from $1.25 \mathrm{~mL}$ of infant formula. One-quarter of the total RNA was used for cDNA synthesis as described above. For quantification of the miRNA and mRNA, $1 / 50$ th of the synthesized cDNA was used.

\section{Statistical Analysis}

The values are expressed as mean \pm standard error of the mean. The significance of differences was determined using Mann-Whitney U-test for comparison between 2 groups, and the Dunnett test or the TukeyKramer honestly significant difference test for multiple comparisons (JMP software; SAS Institute Inc., Cary,
(A)

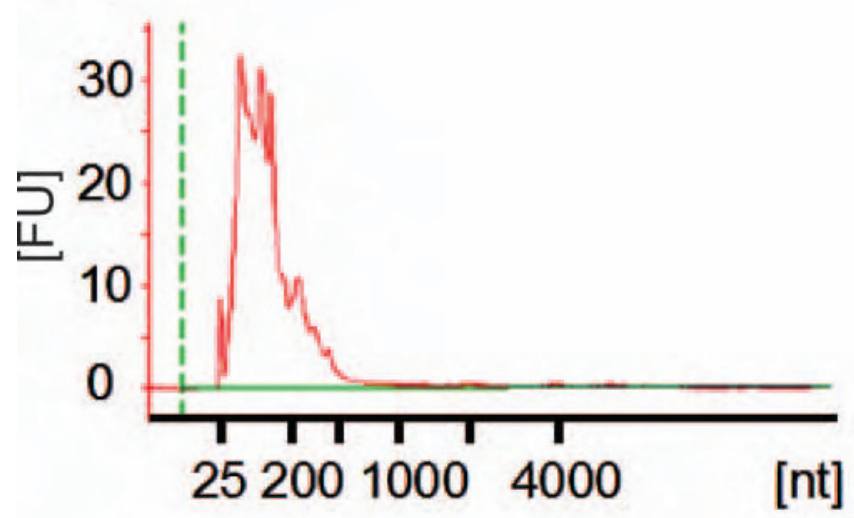

(C)

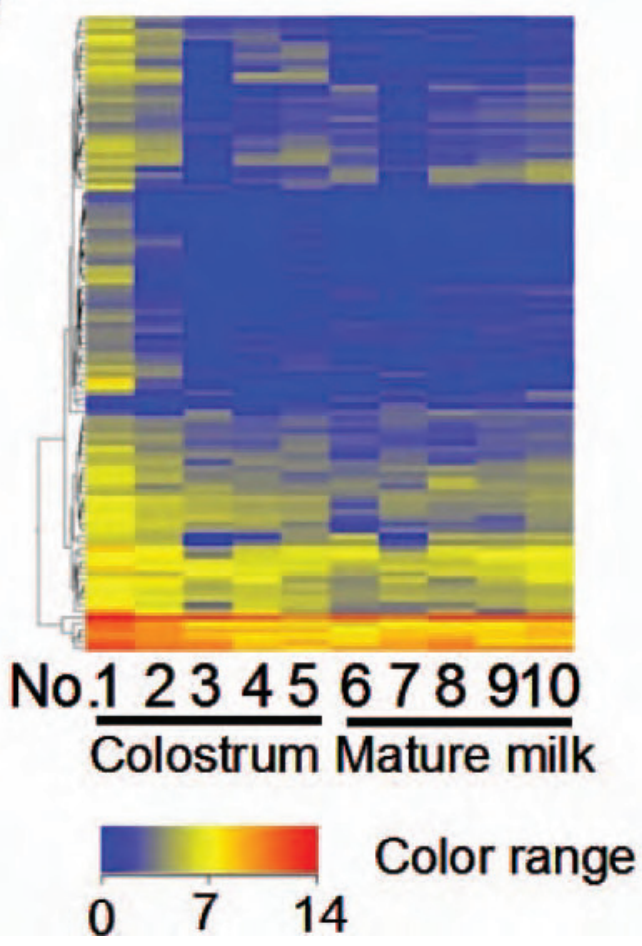

(B)

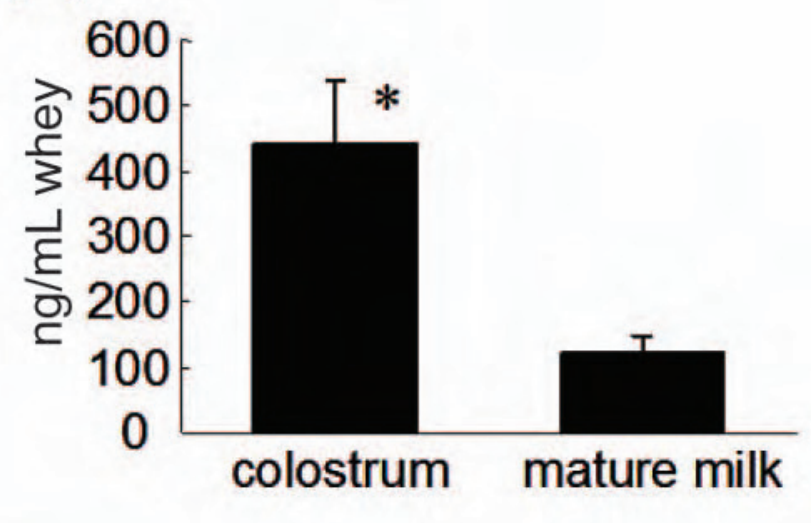

(D)

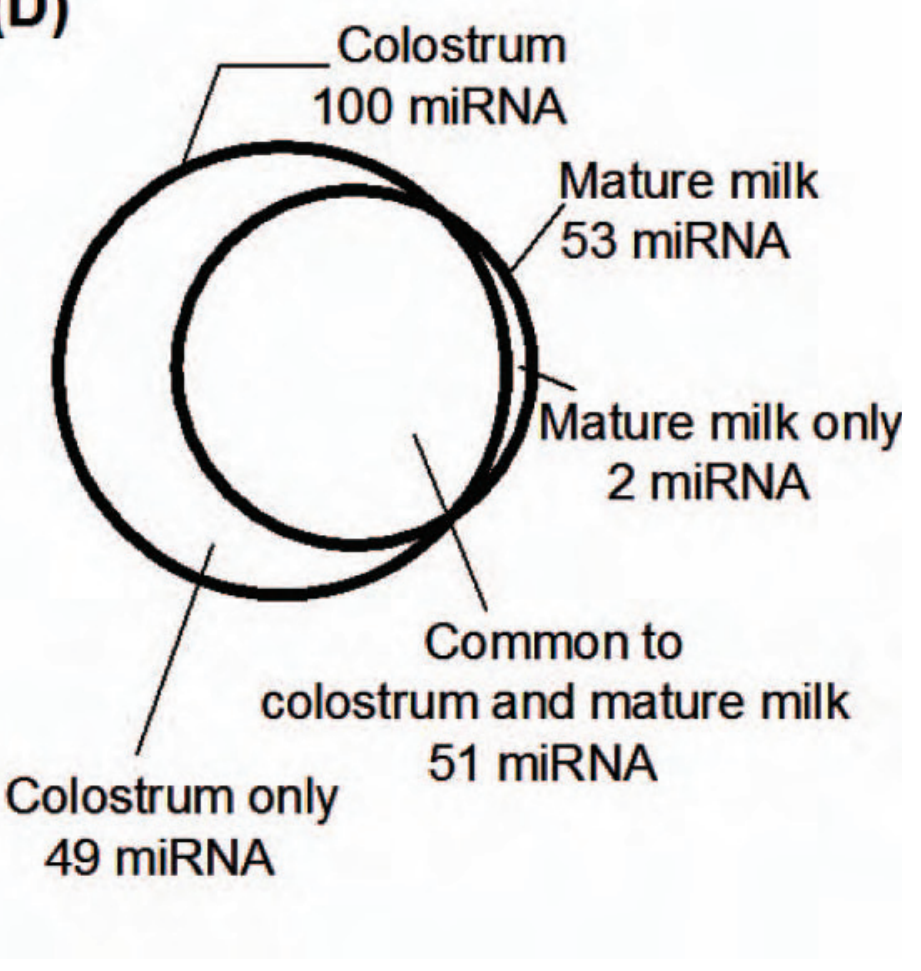

Figure 3. Analysis of the microRNA (miRNA) in bovine milk. (A) Total RNA from bovine milk was analyzed using a bioanalyzer; (B) RNA concentrations (mean $\pm \mathrm{SEM})$ in bovine colostrum and mature milk $(\mathrm{n}=5) ;{ }^{*} P<0.05$ compared with mature milk; (C) miRNA expression gene tree for bovine colostrum and mature milk; (D) Venn diagram showing the numbers of miRNA expressed in bovine colostrum and mature milk. $\mathrm{FU}=$ fluorescence unit. 


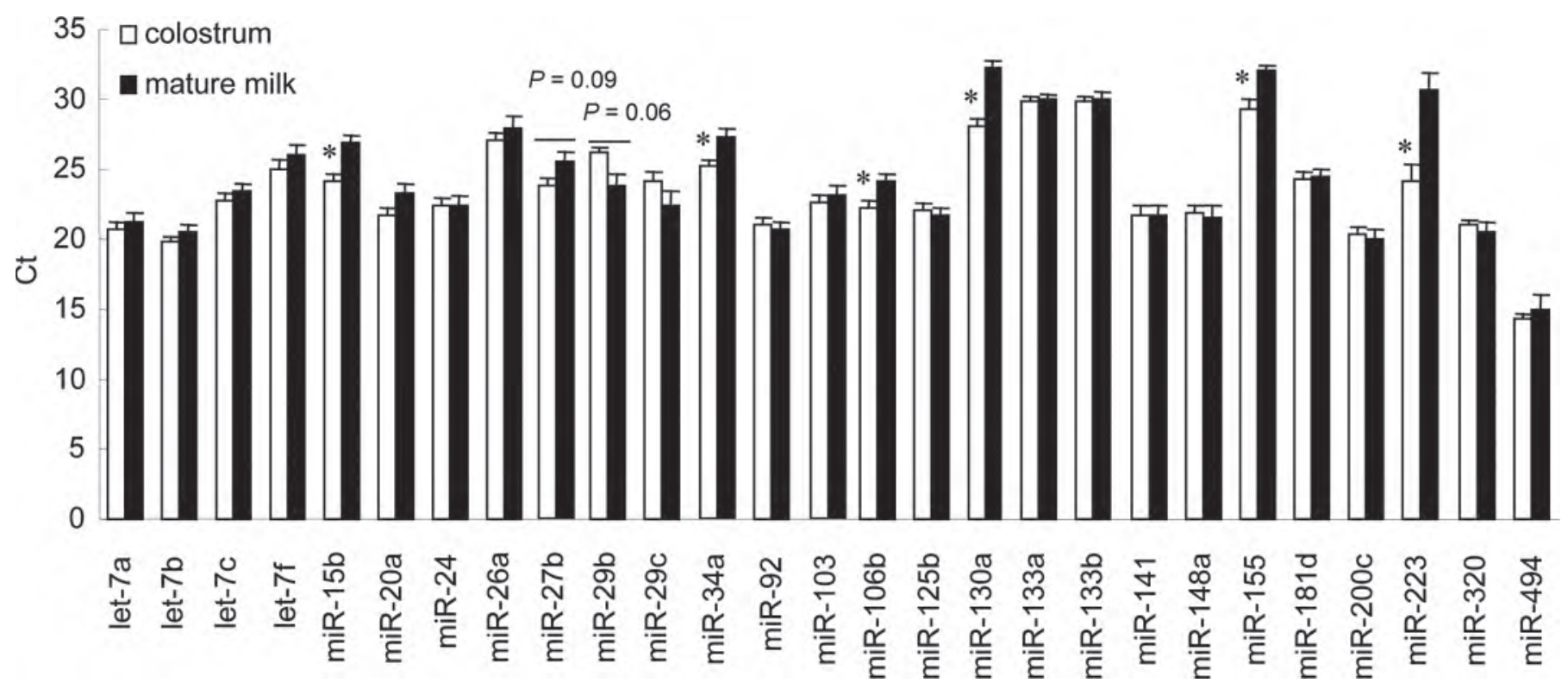

Figure 4. Quantitative PCR analysis (cycle threshold, Ct, values) of select microRNA (miRNA) in equal volumes of RNA from bovine colostrum and mature milk. An aliquot of total RNA $(0.5 \mathrm{ng})$ was used for each miRNA. The values are the mean $\pm \mathrm{SEM}(\mathrm{n}=5) ;{ }^{*} P<0.05$ compared with mature milk.

NC). A $P$-value $<0.05$ was considered a significant difference.

\section{RESULTS AND DISCUSSION}

MicroRNA molecules, a type of endogenous, noncoding small RNA, play important roles in a wide range of physiological processes, including development and differentiation (Bartel, 2004). Over the past few years, several studies have shown that miRNA are present in body fluids, including blood (Mitchell et al., 2008; Weber et al., 2010), urine (Hanke et al., 2010; Weber et al., 2010), saliva (Michael et al., 2010; Weber et al., 2010), and amniotic fluid (Weber et al., 2010). However, most of these studies focused on the potential roles of miRNA as diagnostic biomarkers rather than as biological factors.

Among the different biological fluids, milk and amniotic fluid are provided to offspring. It is thus important to study their biological significance. Breast milk is optimal for infants and can never be equaled by artificial substitutes (Sobti et al., 2002). Nonetheless, interest is growing in making an infant formula that more closely matches breast milk. Infant formula is manufactured from bovine milk. The aims of this study were to assess the miRNA expression profiles of bovine colostrum and mature milk, to speculate on the roles of the miRNA detected, and to determine whether infant formula contains miRNA.
We extracted total RNA from bovine milk and analyzed it using a bioanalyzer. We found no or very little ribosomal RNA (18S and 28S), but small RNA molecules were present (Figure $3 \mathrm{~A}$ ). This suggests that the RNA in milk are not derived from cells in the milk. The RNA concentration in the colostrum whey was significantly higher than that in the mature milk whey (Figure 3B), in agreement with the results of a previous study (Hata et al., 2010).

We next performed miRNA microarray experiments and detected 102 of the 333 known bovine miRNA (Figure 3C). The number of different miRNA detected was higher in colostrum (100 miRNA) than in mature milk (53 miRNA; Figure 3D), and 51 miRNA were common to both colostrum and mature milk. Chen et al. (2010) detected 245 miRNA in bovine milk using an ultra-high-speed sequencer. However, they prepared RNA from a large amount of milk $(100 \mathrm{~mL})$ and purified small RNA by PAGE. Thus, they were able to detect very small amounts of miRNA. This is the likely cause of the differences between our and their results (i.e., our microarray technique only detected miRNA present in milk in relatively large amounts). Only a limited amount of information has been identified experimentally about the roles of miRNA, but immunerelated miRNA are relatively well characterized. Given that milk has a role in infant development, we selected immune-related (Hurteau et al., 2007; Fazi and Nervi, 2008; Lindsay, 2008; Sonkoly et al., 2008; Visone et al., 
2008; Liu et al., 2010; Malumbres and Lossos, 2010; O'Connell et al., 2010; Witwer et al., 2010; Haas et al., 2011; O'Neill et al., 2011) and development-related (Fazi and Nervi, 2008; Itoh et al., 2009; Lynn, 2009; Wang and Olson, 2009; Wang et al., 2009; Aranha et al., 2010; Hennessy et al., 2010; Liao and Lönnerdal, 2010; Wang et al., 2010) miRNA from the 102 miRNA confirmed by microarray for expression analysis by qPCR. All of the selected miRNA were detected by qPCR; however, some differences were found compared with the report of Chen et al. (2010). We detected miR-133b, whereas Chen et al. (2010) did not. Nevertheless, miR-494 was previously detected at relatively high levels in human breast milk (Kosaka et al., 2010b), and we detected it at relatively high levels in bovine milk in the present study. Chen et al. (2010) detected very low levels of miR-494. These differences may be due to the background of the cows whose milk was studied, or to the RNA isolation
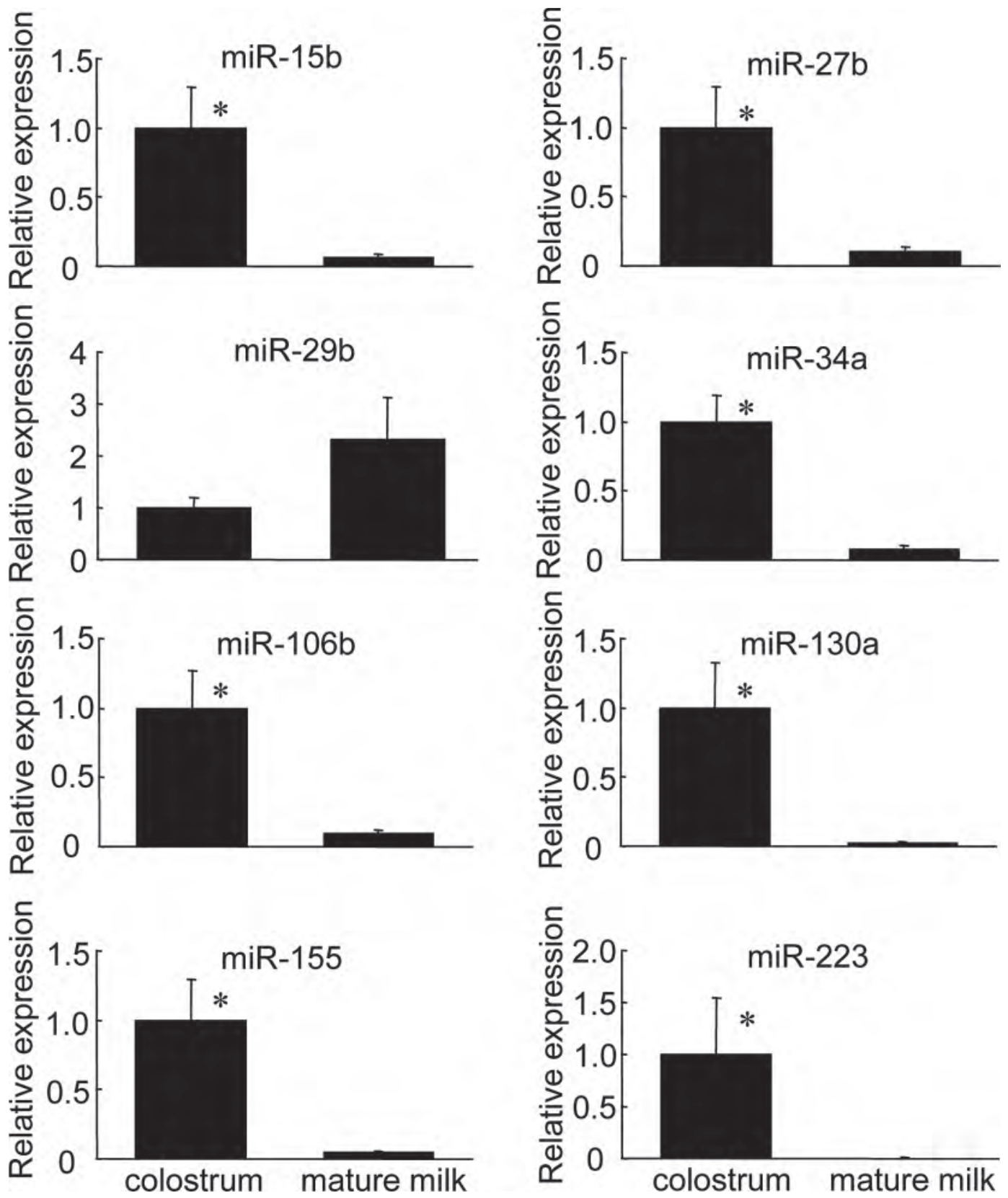

Figure 5. Quantitative PCR analysis of select microRNA (miRNA) with normalization. To measure the levels of expression of miRNA in equal volumes of whey fraction from colostrum and mature milk, the quantitative PCR data obtained were normalized to spiked-in synthetic cel-miR-39. The values are the mean \pm SEM $(\mathrm{n}=5) ;{ }^{*} P<0.05$ compared with mature milk. 


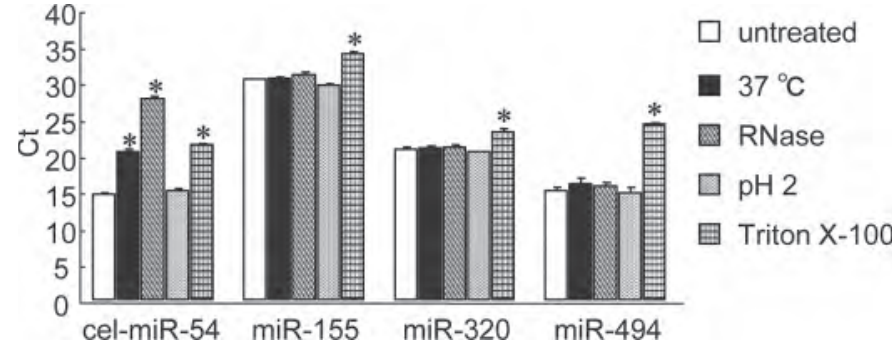

Figure 6. Stability of microRNA (miRNA) cycle threshold $(\mathrm{Ct})$ values in raw bovine milk. Raw milk-derived whey $(400 \mu \mathrm{L})$ was left untreated, incubated at $37^{\circ} \mathrm{C}$ for $1 \mathrm{~h}$ without treatment, incubated at $37^{\circ} \mathrm{C}$ for $1 \mathrm{~h}$ with RNase $(10 \mathrm{U} / \mathrm{mL}$ RNase A and $400 \mathrm{U} / \mathrm{mL}$ RNase $\mathrm{H})$, exposed to a low $\mathrm{pH}(\mathrm{pH} 2)$, or treated with detergent (1\% Triton $\mathrm{X}-100)$. The values are the mean \pm SEM $(\mathrm{n}=3) ;{ }^{*} P<0.05$ compared with untreated.

and detection methods used. The amounts of most of the miRNA selected for qPCR analysis were similar in colostrum and mature milk (when equivalent amounts of RNA were analyzed; Figure 4). However, the levels of some of the miRNA were significantly different (miR15b, miR-34a, miR-106b, miR-155, and miR-223) or tended to be different (miR-29b) between colostrum and mature milk. We thus further analyzed them by normalization using a spiked-in control to determine the levels of these miRNA in equivalent amounts of whey fractions (Figure 5). The levels of immune-related miRNA (miR-15b, miR-27b, miR-106b, miR-155, and miR-223) and development-related miRNA (miR-27b, miR-34a, and miR-130a) were significantly higher in colostrum than in mature milk. Of these, miR-155 and miR-223 were especially interesting because they have been reported to have various immune functions (Lindsay, 2008). Although miR-155 has been linked to the differentiation of $\mathrm{T}$ and $\mathrm{B}$ cells, modulation of the $\mathrm{T}$ helper (Th)1/Th2 balance, and enhanced regulatory $\mathrm{T}$ cell differentiation (Lindsay, 2008), miR-223 is a negative regulator of neutrophil proliferation and activation (Lindsay, 2008); these miRNA thus have antiinflammatory effects.

Generally, RNA is unstable and is rapidly digested by RNase. We investigated the stability of raw milkderived miRNA under different conditions. We chose miRNA that qPCR analysis had shown to have low (miR-155), medium (miR-320), and high (miR-494) relative levels of expression (Figure 4). The miRNA were stable at $37^{\circ} \mathrm{C}$, at a low $\mathrm{pH}$, and in the presence of RNase. In contrast, they were unstable in the presence of detergent (Figure 6). The raw miRNA (celmiR-54) spiked-in to whey directly was not stable at $37^{\circ} \mathrm{C}$ nor in the presence of RNase (Figure 6). Body fluid miRNA have been reported to exist in membrane vesicles such as microvesicles, exosomes, and apoptotic bodies (Simpson et al., 2009; Kosaka et al., 2010a). Exosomes have previously been reported to be present in milk (Admyre et al., 2007; Hata et al., 2010; Kosaka et al., 2010b; Reinhardt et al., 2012). Our results suggest that milk miRNA are packaged in membrane vesicles, allowing them to avoid degradation in the infant gastrointestinal tract and to be absorbed in the intestine. A previous report suggested that human breast milk-derived exosomes could increase the proportion of $\mathrm{CD} 4^{+} \mathrm{CD} 25^{+}$Foxp $^{+}$regulatory $\mathrm{T}$ cells (Admyre et al., 2007). Bovine colostrum was separately reported

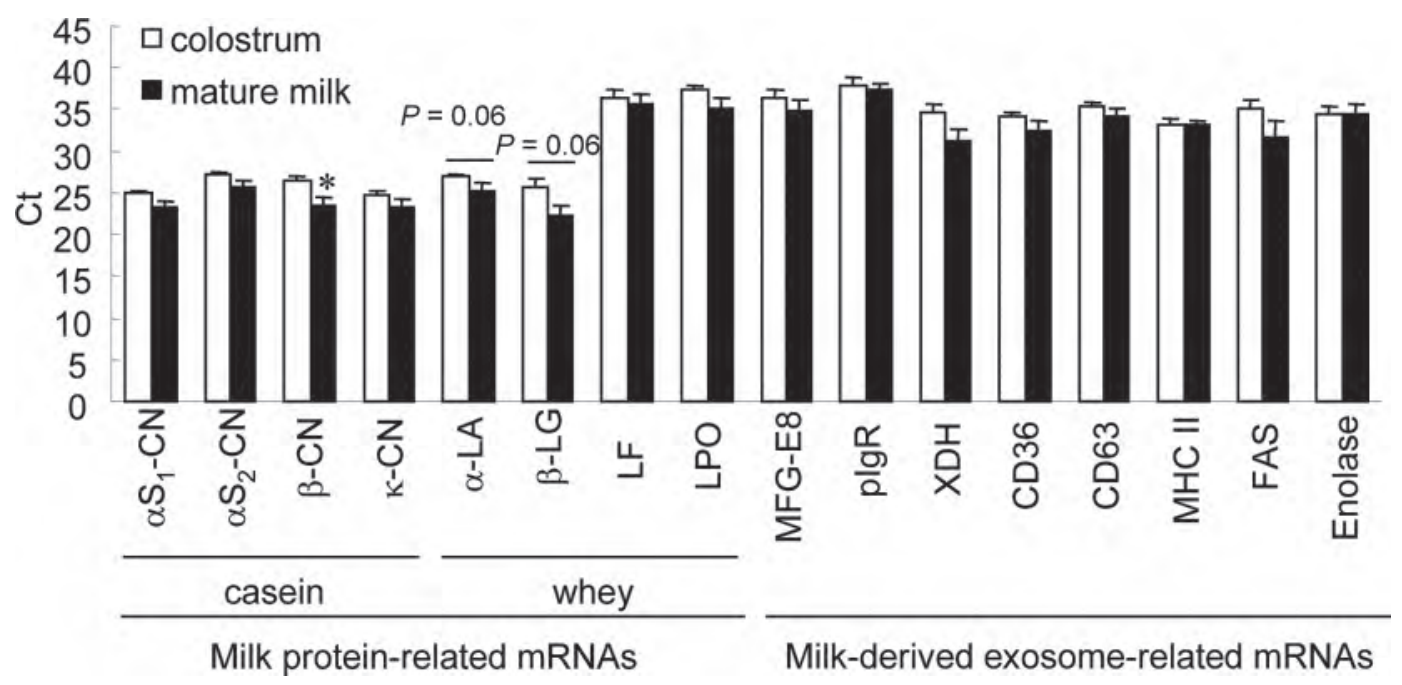

Figure 7. Quantitative PCR analysis (cycle threshold, Ct, values) of mRNA in bovine colostrum and mature milk. An aliquot of total RNA $(0.5 \mathrm{ng})$ was used for each mRNA. The values are the mean $\pm \mathrm{SEM}(\mathrm{n}=5) ;{ }^{*} P<0.05$ compared with colostrum. FAS $=$ fatty acid synthase; $\mathrm{LF}=$ lactoferrin; $\mathrm{LPO}=$ lactoperoxidase; MFG-E8 = milk fat globule-EGF factor 8; MHC II = major histocompatibility complex class II; pIgR $=$ poly Ig receptor; $\mathrm{XDH}=$ xanthine dehydrogenase. 


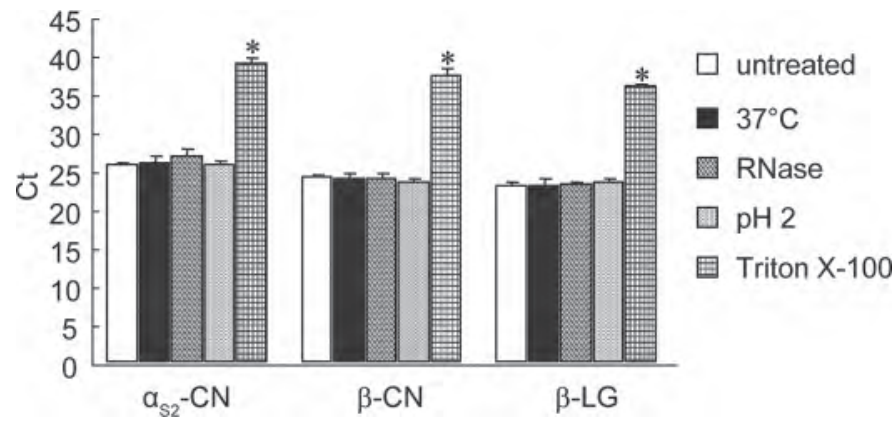

Figure 8. Stability of microRNA (miRNA) cycle threshold (Ct) values in raw bovine milk. Raw milk-derived whey $(400 \mu \mathrm{L})$ was left untreated, incubated at $37^{\circ} \mathrm{C}$ for $1 \mathrm{~h}$ without treatment, incubated at $37^{\circ} \mathrm{C}$ for $1 \mathrm{~h}$ with RNase $(10 \mathrm{U} / \mathrm{mL}$ RNase A and $400 \mathrm{U} / \mathrm{mL}$ RNase $\mathrm{H})$, exposed to a low $\mathrm{pH}(\mathrm{pH} 2)$, or treated with detergent (1\% Triton $\mathrm{X}-100)$. The values are the mean $\pm \operatorname{SEM}(\mathrm{n}=3) ;{ }^{*} P<0.05$ compared with untreated.

to have antiinflammatory effects (An et al., 2009). The mechanism underlying the antiinflammatory effects of milk (especially colostrum) could be partially due to milk miRNA such as miR-155.

A previous report showed that exosomes contain not only miRNA, but also mRNA (Valadi et al., 2007). We therefore assumed that milk also contains mRNA. We selected milk protein-related (caseins, $\alpha$-LA, $\beta$-LG, lactoferrin, lactoperoxidase) and milk-derived exosomerelated protein-encoding mRNA (milk fat globule-EGF factor 8, poly Ig receptor, xanthine dehydrogenase, CD36, CD63, major histocompatibility complex class II, fatty acid synthase, and enolase; Admyre et al., 2007; Reinhardt et al., 2012), and analyzed their expression in colostrum and mature milk by qPCR (Figure 7). Milk protein-related mRNA were present at a relatively high levels. This suggests that the mRNA in milk are generated in the mammary gland. The biological roles of milk protein-related and milk-derived, exosomerelated protein-encoding mRNA remain uncertain. However, previous reports showed that casein mRNA is expressed in monocytes, monocytic cell lines, $\mathrm{T}$ cells, and cytotoxic T-cell lines, and that it may contribute to some immunomodulatory functions (Grusby et al., 1990; Vordenbäumen et al., 2011). The mRNA in milk may have various biological functions. We selected 3 mRNA and used them to investigate the stability of raw milk-derived mRNA. Similar to the milk miRNA, these mRNA were stable at low $\mathrm{pH}$ and in the presence of RNase, but not in the presence of detergent (Figure 8 ). These results and the presence of exosome-related protein-encoding mRNA in milk support the idea that milk RNA are packaged in membrane vesicles. Based on this hypothesis, we suspected that milk RNA could resist the industrial manufacturing process. In fact, Chen et al. (2010) proposed that some miRNA could be new
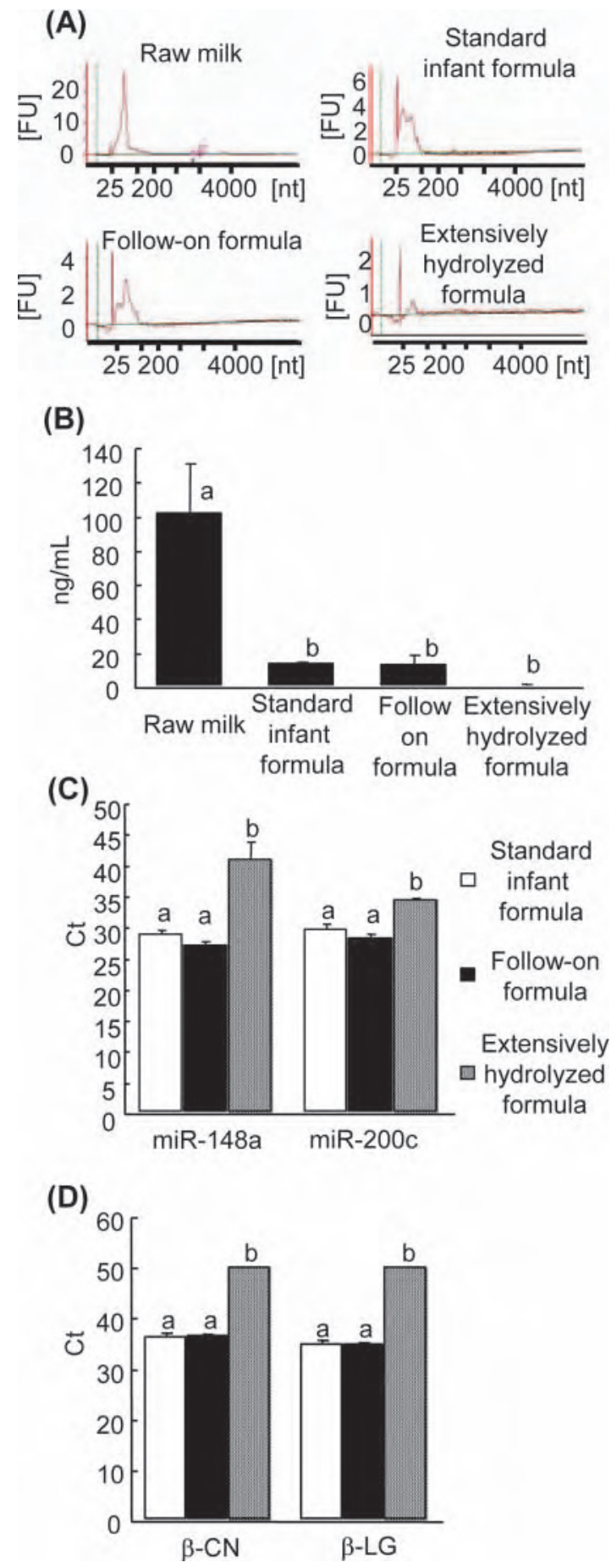

Figure 9. Analysis of infant formula-derived RNA: (A) total RNA from raw bovine milk and infant formulas was analyzed using a bioanalyzer; (B) RNA concentrations in bovine raw milk and infant formulas; (C) microRNA expression in infant formulas (an aliquot of RNA from $1.25 \mathrm{~mL}$ of formula was used); (D) mRNA expression in infant formulas (an aliquot of RNA from $1.25 \mathrm{~mL}$ of formula was used). The mRNA was not detected in extensively hydrolyzed formula; therefore, the formula was assigned a cycle threshold $(\mathrm{Ct})$ value of 50 . The values are the mean \pm SEM $(\mathrm{n}=3)$; means without common letter differ significantly $(P<0.05)$. FU $=$ fluorescence unit. Color version available in the online PDF. 
standards for determining the quality of commercially available Chinese raw milk or milk-related products. The RNA from all infant formulas tested (standard formula, follow-on formula, and extensively hydrolyzed formula) showed peaks corresponding to small RNA (Figure 9A). However, the RNA concentrations were significantly lower in the infant formulas than in raw milk (Figure 9B). We chose 2 miRNA, miR-148a and miR-200c, because Chen et al. (2010) considered them to be suitable for determining the quality of milk products, and we confirmed their expression by qPCR (Figure 4). We next investigated their expression in infant formulas. Although all were detected in infant formulas, their levels were significantly lower in the extensively hydrolyzed formula than in the standard and follow-on formulas (Figure 9C).

We finally selected 2 mRNA (encoding $\beta-\mathrm{CN}$ and $\beta-L G)$ and quantified them by qPCR. These mRNA were detected in standard infant formula and follow-on formula, but could not be detected in extensively hydrolyzed formula (Figure 9D), supporting the hypothesis described above. In general, extensively hydrolyzed formula is fed to milk-allergic infants. For that reason, the protein source in this formula is hydrolyzed by proteases and is passed through a filter to eliminate large peptides. Most of the miRNA and mRNA in milk may exist in membrane vesicles, and may thus be eliminated by filtration because exosomes and microvesicles are 10 $\mathrm{nm}$ to $1 \mu \mathrm{m}$ in diameter (Simpson et al., 2009; Kosaka et al., 2010a), and thus are larger than large ( 10 kDa) peptides.

\section{CONCLUSIONS}

We demonstrated that bovine milk contains miRNA. In addition, we showed that miRNA expression patterns differ between colostrum and mature milk, and that bovine milk contains mRNA. Moreover, we showed that milk RNA are stable under harsh conditions (low $\mathrm{pH}$ and RNase treatment). We further showed that milk RNA could resist the industrial manufacturing process. Additional studies are needed to confirm whether the RNA in bovine milk and infant formulas can function in the infant gastrointestinal tract. It is also necessary to determine milk mRNA expression patterns and to evaluate the roles of milk RNA in infants.

\section{REFERENCES}

Admyre, C., S. M. Johansson, K. R. Qazi, J. J. Filén, R. Lahesmaa, M. Norman, E. P. Neve, A. Scheynius, and S. Gabrielsson. 2007. Exosomes with immune modulatory features are present in human breast milk. J. Immunol. 179:1969-1978.

An, M. J., J. H. Cheon, S. W. Kim, J. J. Park, C. M. Moon, S. Y. Han, E. S. Kim, T. I. Kim, and W. H. Kim. 2009. Bovine colostrum in- hibits nuclear factor kappaB-mediated proinflammatory cytokine expression in intestinal epithelial cells. Nutr. Res. 29:275-280.

Aranha, M. M., D. M. Santos, J. M. Xavier, W. C. Low, C. J. Steer, S. Solá, and C. M. P. Rodrigues. 2010. Apoptosis-associated microRNAs are modulated in mouse, rat and human neural differentiation. BMC Genomics 11:514.

Bartel, D. P. 2004. MicroRNAs: Genomics, biogenesis, mechanism, and function. Cell 116:281-297.

Burrin, D. G., and B. Stoll. 2002. Key nutrients and growth factors for the neonatal gastrointestinal tract. Clin. Perinatol. 29:65-96.

Chen, X., C. Gao, H. Li, L. Huang, Q. Sun, Y. Dong, C. Tian, S. Gao, H. Dong, D. Guan, X. Hu, Z. Shujian, L. Li, L. Zhu, Q. Yan, J. Zhang, K. Zen, and C. Y. Zhang. 2010. Identification and characterization of microRNAs in raw milk during different periods of lactation, commercial fluid, and powdered milk products. Cell Res. 20:1128-1137.

Davis, T. A., H. V. Nguyen, R. Garcia-Bravo, M. L. Fiorotto, E. M. Jackson, and P. J. Reeds. 1994. Amino acid composition of the milk of some mammalian species changes with stage of lactation. Br. J. Nutr. 72:845-853.

Fazi, F., and C. Nervi. 2008. MicroRNA: Basic mechanisms and transcriptional regulatory networks for cell fate determination. Cardiovasc. Res. 79:553-561.

Goldman, A. S. 2007. The immune system in human milk and the developing infant. Breastfeed. Med. 2:195-204.

Grusby, M. J., S. C. Mitchell, N. Nabavi, and L. H. Glimcher. 1990. Casein expression in cytotoxic T lymphocytes. Proc. Natl. Acad. Sci. USA 87:6897-6901.

Haas, J. D., K. Nistala, F. Petermann, N. Saran, V. Chennupati, S. Schmitz, T. Korn, L. R. Wedderburn, R. Förster, A. Krueger, and I. Prinz. 2011. Expression of miRNAs miR-133b and miR-206 in the Il17a/f locus is co-regulated with IL-17 production in $\alpha \beta$ and $\gamma \delta$ T cells. PLoS ONE 6:e20171.

Hanke, M., K. Hoefig, H. Merz, A. C. Feller, I. Kausch, D. Jocham, J. M. Warnecke, and G. Sczakiel. 2010. A robust methodology to study urine microRNA as a tumor marker: MicroRNA-126 and microRNA-182 are related to urinary bladder cancer. Urol. Oncol. $28: 655-661$

Hata, T., K. Murakami, H. Nakatani, Y. Yamamoto, T. Matsuda, and N. Aoki. 2010. Isolation of bovine milk-derived microvesicles carrying mRNAs and microRNAs. Biochem. Biophys. Res. Commun. 396:528-533.

Hennessy, E., M. Clynes, P. B. Jeppesen, and L. O’Driscoll. 2010. Identification of microRNAs with a role in glucose-stimulated insulin secretion by expression profiling of MIN6 cells. Biochem. Biophys. Res. Commun. 396:457-462.

Hurteau, G. J., A. J. Carlson, S. D. Spivack, and G. J. Brock. 2007. Overexpression of the microRNA hsa-miR-200c leads to reduced expression of transcription factor 8 and increased expression of $\mathrm{E}$ cadherin. Cancer Res. 67:7972-7976.

Itoh, T., Y. Nozawa, and Y. Akao. 2009. MicroRNA-141 and -200a are involved in bone morphogenetic protein-2-induced mouse preosteoblast differentiation by targeting distal-less homeobox 5 . J. Biol. Chem. 284:19272-19279.

Izumi, H., S. Ishizuka, A. Inafune, T. Hira, K. Ozawa, T. Shimizu, M. Takase, and H. Hara. 2009. $\alpha$-Lactalbumin hydrolysate stimulates glucagon-like peptide-2 secretion and small intestinal growth in suckling rats. J. Nutr. 139:1322-1327.

Jensen, R. G. 1995. Handbook of Milk Composition. Academic Press, San Diego, CA.

Kosaka, N., H. Iguchi, and T. Ochiya. 2010a. Circulating microRNA in body fluid: A new potential biomarker for cancer diagnosis and prognosis. Cancer Sci. 101:2087-2092.

Kosaka, N., H. Izumi, K. Sekine, and T. Ochiya. 2010b. MicroRNA as a new immune-regulatory agent in breast milk. Silence 1:7.

Lewis, B. P., C. B. Burge, and D. P. Bartel. 2005. Conserved seed pairing, often flanked by adenosines, indicates that thousands of human genes are microRNA targets. Cell 120:15-20.

Liao, Y., and B. Lönnerdal. 2010. Global microRNA characterization reveals that miR-103 is involved in IGF-1 stimulated mouse intestinal cell proliferation. PLoS ONE 5:e12976. 
Lindsay, M. A. 2008. MicroRNAs and the immune response. Trends Immunol. 29:343-351.

Liu, X., Z. Zhan, L. Xu, F. Ma, D. Li, Z. Guo, N. Li, and X. Cao. 2010. MicroRNA-148/152 impair innate response and antigen presentation of TLR-triggered dendritic cells by targeting CaMKII $\alpha$. J. Immunol. 185:7244-7251.

Lynn, F. C. 2009. Meta-regulation: MicroRNA regulation of glucose and lipid metabolism. Trends Endocrinol. Metab. 20:452-459.

Malumbres, R., and I. S. Lossos. 2010. Expression of miRNAs in lymphocytes: A review. Methods Mol. Biol. 667:129-143.

Michael, A., S. D. Bajracharya, P. S. Yuen, H. Zhou, R. A. Star, G. G. Illei, and I. Alevizos. 2010. Exosomes from human saliva as a source of microRNA biomarkers. Oral Dis. 16:34-38.

Mitchell, P. S., R. K. Parkin, E. M. Kroh, B. R. Fritz, S. K. Wyman, E. L. Pogosova-Agadjanyan, A. Peterson, J. Noteboom, K. C. O'Briant, A. Allen, D. W. Lin, N. Urban, C. W. Drescher, B. S. Knudsen, D. L. Stirewalt, R. Gentleman, R. L. Vessella, P. S. Nelson, D. B. Martin, and M. Tewari. 2008. Circulating microRNAs as stable blood-based markers for cancer detection. Proc. Natl. Acad. Sci. USA 105:10513-10518.

O'Connell, R. M., D. S. Rao, A. A. Chaudhuri, and D. Baltimore. 2010. Physiological and pathological roles for microRNAs in the immune system. Nat. Rev. Immunol. 10:111-122.

O'Neill, L. A., F. J. Sheedy, and C. E. McCoy. 2011. MicroRNAs: The fine-tuners of toll-like receptor signaling. Nat. Rev. Immunol. 11:163-175.

Reinhardt, T. A., J. D. Lippolis, B. J. Nonnecke, and R. E. Sacco. 2012. Bovine milk exosome proteome. J. Proteomics 75:14861492.

Simpson, R. J., J. W. Lim, R. L. Moritz, and S. Mathivanan. 2009. Exosomes: Proteomic insights and diagnostic potential. Expert Rev. Proteomics 6:267-283.

Sobti, J., G. P. Mathur, and A. Gupta. 2002. WHO's proposed global strategy for infant and young child feeding: A viewpoint. J. Indian Med. Assoc. 100:502-504.

Sonkoly, E., M. Ståhle, and A. Pivarcsi. 2008. MicroRNAs and immunity: Novel players in the regulation of normal immune function and inflammation. Semin. Cancer Biol. 18:131-140.
Valadi, H., K. Ekström, A. Bossios, M. Sjöstrand, J. J. Lee, and J. O. Lötvall. 2007. Exosome-mediated transfer of mRNAs and microRNAs is a novel mechanism of genetic exchange between cells. Nat. Cell Biol. 9:654-659.

Visone, R., F. Petrocca, and C. M. Croce. 2008. Micro-RNAs in gastrointestinal and liver disease. Gastroenterology 135:1866-1869.

Vordenbäumen, S., A. Braukmann, K. Petermann, A. Scharf, E. Bleck, A. von Mikecz, J. Jose, and M. Schneider. 2011. Casein as1 is expressed by human monocytes and upregulates the production of GM-CSF via p38 MAPK. J. Immunol. 186:592-601.

Walker, A. 2010. Breast milk as the gold standard for protective nutrients. J. Pediatr. 156:S3-S7.

Wang, S., and E. N. Olson. 2009. AngiomiRs-Key regulators of angiogenesis. Curr. Opin. Genet. Dev. 19:205-211.

Wang, X., X. Zhang, X. P. Ren, J. Chen, H. Liu, J. Yang, M. Medvedovic, Z. Hu, and G. C. Fan. 2010. MicroRNA-494 targeting both proapoptotic and antiapoptotic proteins protects against ischemia/ reperfusion-induced cardiac injury. Circulation 122:1308-1318.

Wang, X. H., R. Z. Qian, W. Zhang, S. F. Chen, H. M. Jin, and R. M. Hu. 2009. MicroRNA-320 expression in myocardial microvascular endothelial cells and its relationship with insulin-like growth factor-1 in type 2 diabetic rats. Clin. Exp. Pharmacol. Physiol. $36: 181-188$.

Weber, J. A., D. H. Baxter, S. Zhang, D. Y. Huang, K. H. Huang, M. J. Lee, D. J. Galas, and K. Wang. 2010. The microRNA spectrum in 12 body fluids. Clin. Chem. 56:1733-1741.

Witwer, K. W.. J. M. Sisk, L. Gama, and J. E. Clements. 2010. MicroRNA regulation of IFN-beta protein expression: Rapid and sensitive modulation of the innate immune response. J. Immunol. 184:2369-2376.

Zhang, L., D. Hou, X. Chen, D. Li, L. Zhu, Y. Zhang, J. Li, Z. Bian, X. Liang, X. Cai, Y. Yin, C. Wang, T. Zhang, D. Zhu, D. Zhang, J. Xu, Q. Chen, Y. Ba, J. Liu, Q. Wang, J. Chen, J. Wang, M Wang, Q. Zhang, J. Zhang, K. Zen, and C. Y. Zhang. 2012. Exogenous plant MIR168a specifically targets mammalian LDLRAP1: Evidence of cross-kingdom regulation by microRNA. Cell Res. 22:107-126. 